\title{
Vitamin Analysis, Trace Elements Content, and Their Extractabilities in Tetrapleura tetraptera
}

\author{
Prince Oteng $\mathbb{D}^{1,2}$, John K. Otchere, ${ }^{2}$ Stephen Adusei, ${ }^{2,3}$ Richard Q. Mensah, \\ and Emmanuel Tei-Mensah ${ }^{2,5}$ \\ ${ }^{1}$ Department of Chemistry, University of Cape Coast, Cape Coast, Ghana \\ ${ }^{2}$ Department of Laboratory Technology, University of Cape Coast, Cape Coast, Ghana \\ ${ }^{3}$ Department of Environmental Science, University of Cape Coast, Cape Coast, Ghana \\ ${ }^{4}$ Department of Biomedical Engineering, University of Ghana, Legon, Accra, Ghana \\ ${ }^{5}$ Department of Food and Postharvest Technology, Koforidua Technical University, Koforidua, Ghana
}

Correspondence should be addressed to Prince Oteng; otengprince0508@gmail.com

Received 16 July 2019; Accepted 21 December 2019; Published 11 January 2020

Academic Editor: Isabel Mafra

Copyright ( 2020 Prince Oteng et al. This is an open access article distributed under the Creative Commons Attribution License, which permits unrestricted use, distribution, and reproduction in any medium, provided the original work is properly cited.

\begin{abstract}
Tetrapleura tetraptera is widely cherished in African traditional homes because of its alleged therapeutic and nutritional properties. This present study aimed at determining the levels of vitamin $\mathrm{A}, \mathrm{C}, \mathrm{E}$, and beta-carotene and trace element ( $\mathrm{Fe}, \mathrm{Cu}, \mathrm{Mn}$, $\mathrm{Co}, \mathrm{Se}$, and $\mathrm{Zn}$ ) concentrations and their extractabilities in the pulp, seeds, and whole fruit (mixture of pulp and seeds) of $T$. tetraptera. The total trace element concentration of $\mathrm{Fe}, \mathrm{Cu}, \mathrm{Co}, \mathrm{Mn}$, and $\mathrm{Zn}$ and their extractabilities (\%) were determined using flame atomic absorption spectrometer (FAAS), whereas UV-VIS spectrophotometer was used to determine selenium concentration. The trace element content $(\mathrm{mg} / \mathrm{kg})$ based on dry weight in the pulp, seeds, and whole fruit was Fe $(162.00 \pm 7.14$,

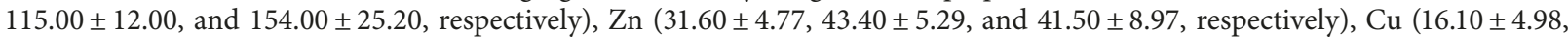
$11.90 \pm 8.40$, and $17.20 \pm 14.50$, respectively), $\mathrm{Mn}(55.30 \pm 2.41,156.00 \pm 10.20$, and $122.00 \pm 5.29$, respectively), Co (38.10 \pm 6.40 , $21.10 \pm 7.15$, and $44.00 \pm 14.90$, respectively), and Se $(1.49 \pm 0.17,2.43 \pm 0.28$, and $2.97 \pm 0.27 \mu \mathrm{g} / \mathrm{g}$, respectively). The mineral extractabilities (\%) in the pulp, seeds, and whole fruit of $T$. tetraptera were established to be in the order $\mathrm{Co}>\mathrm{Zn}>\mathrm{Fe}>\mathrm{Cu}>\mathrm{Se}>\mathrm{Mn}$. Also, the chromatographic method (HPLC) was used to evaluate vitamin E concentration, and vitamin $\mathrm{C}$ and concentration of beta-carotene were calculated from the obtained concentration of vitamin $\mathrm{A}$ using a conversion factor by the titrimetric method. From the results of vitamin analysis, a significant difference $(p<0.05)$ was observed among the pulp, seeds, and whole fruit for vitamin C and E. However, no significant difference $(p>0.05)$ was perceived among these plant parts for vitamin A and beta-carotene. This study has therefore revealed that the pulp, seeds, and whole fruit of T. tetraptera contain varying concentrations of vitamins and trace elements and has given many vital insights on which part of T. tetraptera to consume, as concentrations of these nutrients differ in the discrete parts of the fruit.
\end{abstract}

\section{Introduction}

Ghana is rich in many important tropical plants and one of such plants is Tetrapleura tetraptera, locally known as "Prekese." It is highly valued in Ghana and beyond for its nutritional and medicinal properties. The T. tetraptera plant is a leguminous multipurpose tree that belongs to the family Fabaceae, which can growth to a height of $20-35 \mathrm{~m}$ with a girth of $1.5-3 \mathrm{~m}$ [1]. It is a deciduous plant which is usually located in the lowland rainforest of tropical Africa, particularly in Western African countries such as Ghana, Nigeria, and Cameroon. The dry powdered fruit is used in soap making to increase the antimicrobial activity and improve the foaming ability of soaps [2]. This has contributed to the enormous use of the T. tetraptera fruits in many African homes. The T. tetraptera fruits are also used in the cooking of soup or porridge for nursing mothers to eliminate postpartum contraction, aid in lactation, and manage convulsions, leprosy, inflammation, and rheumatism $[3,4]$. The fruits have been reported to have strong 
molluscidal, antimicrobial, anticonvulsant, and insecticidal activities [5] and are important compounds for the management of a collection of ailments including diabetes, arthritis, malaria, fever, and hypertension [6]. Tetrapleura tetraptera is believed to be nutritious.

Trace elements are inorganic substances that are present in all body tissues and fluids, and their presence is vital for the maintenance of certain physicochemical processes that are essential to life. Although they do not provide energy, they have significant roles in many activities in the body [7]. Generally, they are needed by the body for normal growth, development, and physiology. Some minerals such as $\mathrm{Ca}, \mathrm{Mg}, \mathrm{Na}, \mathrm{K}, \mathrm{P}$, and $\mathrm{S}$ are needed in larger amounts to perform essential functions of life [8]. However, other minerals are required in smaller amounts, and these are referred to as trace elements, which include $\mathrm{Fe}, \mathrm{Cu}, \mathrm{Mn}, \mathrm{Co}, \mathrm{F}, \mathrm{I}$, and $\mathrm{Zn}$. Trace elements are very important in the health and disease states of humans and domestic animals. For example, one trace element of crucial importance to people with HIV is selenium, which is an antioxidant that increases immune function [9]. Inadequate intake of these trace elements or metals can lead to symptoms of nutritional deficiency. However, high intake of trace elements beyond recommended limits may lead to metal poisoning, neurological disorders, and many others [10].

Mineral extractability (\%) is an index of bioavailability that represents the amount of minerals that would be available for absorption into the body. Mineral extractability is complicated and dependent upon a number of factors related to mineral solubility and absorbability. The fraction of an ingested trace mineral that can be used by the organism is of major importance, and several factors influence its availability: chemical state of the element, its release from the food matrix, possible interaction with other trace elements, presence of suppressors and cofactor formation of stable compounds that are slowly metabolized, and so on [11]. Absorption of one mineral can reduce the absorption of another mineral. For example, there are absorptive interactions between iron, zinc, and copper and between calcium and magnesium [12]. These interactions have therapeutic uses; oral zinc supplementation inhibits copper absorption in patients with Wilson's disease who have excessive tissue copper loads [12].

Vitamins are organic compounds that are needed in smaller amount for the normal growth and development of an organism. Vitamins cannot be synthesized by organisms, and thus they have to be obtained from ingested foods. Ascorbic acid, also called vitamin C, plays a role in healing of wounds in humans. Vitamin $\mathrm{C}$ is a water-soluble vitamin that is available in many fruits, vegetables, and dietary supplements. Humans cannot synthesize vitamin C endogenously; therefore, it is an important food component [13]. Vitamin E, on the other hand, is a collective name of a group of fat-soluble vitamins that has some distinctive antioxidant activities [14]. Naturally occurring vitamin E appears in eight chemical forms, viz, alpha-, beta-, gamma-, and delta-tocopherol and alpha-, beta-, gamma-, and deltatocotrienol [14].
Beta-carotene is also a form of natural substance that gives colour to plants (pigment). Yellow and orange fruits and vegetables get their rich hue from beta-carotene. Betacarotene is the most abundant carotenoid that can be converted to vitamin $\mathrm{A}$ in the human body. The main dietary source of vitamin A, which is significant for normal growth, development, vision, and immune system function, is betacarotene [15]. Studies have revealed the presence of vitamins and trace elements in the pulp and sometimes in the seeds of T. tetraptera. However, less data has been provided on the whole fruit (pulp and seeds). In this study, we determined vitamins level, trace element concentrations, and their extractabilities in the pulp, seeds, and whole fruit of T. tetraptera. It is expected that this study will contribute to further understanding of trace element extractability and nutritional composition of T. tetraptera fruit.

\section{Materials and Methods}

2.1. Sample Collection. Matured Tetrapleura tetraptera pods were purchased randomly from different vendors at the Kotokroba market in Cape Coast, Ghana. The samples were kept in paper bags and transported to the laboratory for processing.

2.2. Sample Preparation. The samples were washed with distilled water and sun-dried. The dried pods were cut open to separate the seeds from the pulp. The obtained pulp and seeds were milled into fine powders, while the whole fruit was obtained by milling the pulp and seeds together. The powdered samples were packaged into separate airtight ziploc bags for storage pending extraction and analysis.

\subsection{Sample Extraction}

2.3.1. Extraction of Water-Soluble Vitamin (Vitamin C). Vitamin $\mathrm{C}$ was extracted according to a modification of the method by [16]. Ten grams of $T$. tetraptera powder was homogenized with an extraction solution containing $0.3 \mathrm{M}$ metaphosphoric acid and $1.4 \mathrm{M}$ acetic acid. The mixture was transferred into a conical flask and agitated at 10,000 revolutions per minute (rpm) for 15 minutes and then filtered through a Whatman number 4 filter paper to get the extract. Extraction was carried out in triplicate.

2.3.2. Extraction of Fat-Soluble Vitamins (Vitamin A, E, and Beta-Carotene). Vitamin A, E, and beta-carotene were extracted by adding $10 \mathrm{~g}$ of homogenized $T$. tetraptera powder to $1 \mathrm{~g}$ pyrogallic acid, $70 \mathrm{~mL}$ of ethanol, and $30 \mathrm{~mL}$ (50\%) potassium hydroxide. The mixture was stirred and refluxed for 40 minutes at $50^{\circ} \mathrm{C}$ with a water bath. The sample was extracted in triplicate using ether. The extract obtained was neutralized using double-distilled water, which was then dehydrated using anhydrous sodium sulphate. The extract was further concentrated at $50^{\circ} \mathrm{C}$ using a water bath, diluted to $10 \mathrm{~mL}$ with methanol, and then filtered through a $0.45 \mu \mathrm{m}$ membrane $[17,18]$. 


\subsection{Vitamin A, C, E, and Beta-Carotene Determinations}

2.4.1. Quantification of Vitamin A Using the Spectrophotometric Method. Two milliliters $(2 \mathrm{~mL})$ of the extracted sample were measured into a test tube with a tight stopper and labelled as test tube 1 . One milliliter of potassium hydroxide solution (1 $\mathrm{M}$ solution of $\mathrm{KOH}$ in $90 \%$ ethanol) was added to the liquid in the test tube 1 and shaken vigorously for 1 minute. The test tube 1 was heated in a water bath at $60^{\circ} \mathrm{C}$ for 20 minutes and then cooled using cold water. Two milliliters of xylene was added to the cooled solution and shaken for 1 minute and then centrifuged at $1500 \mathrm{rpm}$ for 10 minutes. The supernatant (upper layer) was collected and transferred into another test tube labelled test tube II. The extract was analyzed by measuring the absorbance at a wavelength of $335 \mathrm{~nm}$ against xylene and named $A_{1}$. The extract in the test tube labelled II was exposed to UV light for 30 minutes, and the absorbance was measured and named $A_{2}$. The concentration of vitamin $\mathrm{A}$ in the extract was determined by applying the formula $C_{x}=\left(A_{1}-A_{2}\right) \times 22.23$, where the value 22.23 was obtained from the absorbance of the absorption coefficient of $1 \%$ solution of retinol in xylene at $335 \mathrm{~nm}$ in a measuring cuvette of about $1 \mathrm{~cm}$ thickness [19].

\subsubsection{Quantification of Vitamin C Using Modified Iodometric} Titration. Vitamin C in the extracts was quantified using the iodometric titration method. In the titrimetric method, a standard solution of sodium thiosulphate $\left(\mathrm{Na}_{2} \mathrm{~S}_{2} \mathrm{O}_{3}\right)$ of concentration $0.05 \mathrm{M}$ and a starch indicator were used. A burette was filled with $0.05 \mathrm{M}$ sodium thiosulphate and titrated against the analyte $(10 \mathrm{~mL}$ of extract, $10 \mathrm{~mL}$ of iodine solution, and 3 drops of starch indicator) until the colour changed from blue-black to colourless. The volume of the thiosulphate that resulted in the colour change was observed and recorded. To know the concentration of the iodine solution and the amount of ascorbic acid in the sample that reacted with the iodine, the thiosulphate solution was titrated against a blank, which was composed of distilled water, iodine solution, and starch indicator. With the help of stoichiometry, the amount as well as the concentration of ascorbic acid was determined [20].

$$
\begin{gathered}
\mathrm{IO}_{3}^{-}+8 \mathrm{I}^{-}+6 \mathrm{H}^{+} \rightleftharpoons 3 \mathrm{I}_{3}^{-}+3 \mathrm{H}_{2} \mathrm{O} \\
\mathrm{I}_{3}^{-}+2 \mathrm{~S}_{2} \mathrm{O}_{3}^{2-} \rightleftharpoons 3 \mathrm{I}^{-}+\mathrm{S}_{4} \mathrm{O}_{6}^{2-} \\
\mathrm{H}_{2} \mathrm{O}+\mathrm{I}_{3}^{-}+\mathrm{C}_{6} \mathrm{H}_{8} \mathrm{O}_{6} \rightleftharpoons \mathrm{C}_{6} \mathrm{H}_{8} \mathrm{O}_{6}+3 \mathrm{I}_{3}^{-}+3 \mathrm{H}^{+}
\end{gathered}
$$

The abovementioned equations show the preparation of triiodide and the reaction between triiodide and thiosulphate and triiodide and ascorbic acid, respectively [21].

2.4.3. Quantification of Vitamin E Using HPLC. The reversephase (RP) HPLC analysis of vitamin E was performed on an Agilent 1100 series HPLC system with a diode array detector. In the quantification of vitamins $\mathrm{E}$, the column used was Agilent eclipse XDB-C18, with methanol as the only used eluent. The wavelength for the UV detection of vitamin $\mathrm{E}$ was $290 \mathrm{~nm}$. The separation of the vitamin was on the basis of isocratic elution and maintenance of the solvent flow rate at $1.0 \mathrm{~mL} / \mathrm{min}$. The identification of vitamin $\mathrm{E}$ was achieved by comparing the retention times to that of authentic standards [22].

2.4.4. Quantification of Beta-Carotene Content. Based on the knowledge that beta-carotene is a provitamin of vitamin A, the quantity of beta-carotene was determined from the obtained concentration of vitamin A (retinol). Thus, vitamin A was converted to beta-carotene by first converting the concentration of vitamin A in the samples to mass of vitamin A using the equation: Mass $=$ concentration $\times$ volume $\times$ molar mass of retinol. The mass of vitamin A obtained was in milligrams, which was converted to the international unit of retinol. The values of retinol obtained in international units were then converted to composition beta-carotene through multiplication of the values by $0.6 \mu \mathrm{g}$ beta-carotene. The concentration of beta-carotene was then determined by the relation: Concentration of beta-carotene $=$ mass of beta-carotene/volume of extract $\times$ molar mass of beta-carotene [23].

\subsection{Trace Elements Analysis}

2.5.1. Determination of $\mathrm{Fe}, \mathrm{Cu}, \mathrm{Mn}, \mathrm{Co}$, and $\mathrm{Zn}$. All glasswares were washed neatly in a detergent, soaked in $10 \%$ nitric acid for 4 hours and finally rinsed with deionized water before use. Analytical reagent-grade chemicals and distilled water were used for the preparation of all the solutions that were needed. Powdered samples of T. tetraptera pulp, seeds, and whole fruit were digested according to a method described by [24]. Three powdered samples, $0.5 \mathrm{~g}$ each, were weighed using the analytical balance and transferred into clean well-labelled beakers. Five milliliters of $65 \% \mathrm{HNO}_{3}$ was added to each of the beakers containing the samples, and the solution mixtures were boiled gently for 30 minutes after which they were allowed to cool and $2.5 \mathrm{~mL}$ of $70 \% \mathrm{HClO}_{4}$ was also added to the beakers. The solution mixtures were gently boiled until dense white fumes appeared. The solution mixtures were allowed to cool, and $10 \mathrm{~mL}$ of distilled water was added to each beaker, followed by further boiling until the fumes were totally released. The prepared digest solutions were diluted to the $50 \mathrm{~mL}$ mark and transferred into clean plastic containers for the elemental analysis using the flame atomic absorption spectrometer.

2.5.2. Determination of Selenium (Se). Analytical reagentgrade chemicals and distilled water were used for the preparation of all the solutions that were needed. Selenium in the powdered samples was determined using a spectrophotometer according to a method described by [25]. One gram, each of the pulp, seeds, and whole fruit, was weighed into clean beakers and boiled gently with $10 \mathrm{~mL}$ of $65 \% \mathrm{HNO}_{3}$ for 20 minutes. Half a milliliter $(0.5 \mathrm{~mL})$ of $70 \%$ perchloric acid was added to each of the sample solutions after cooling. Heating was continued for another 10 minutes and then allowed to 
cool. Ten milliliters of distilled water and $5 \mathrm{~mL}$ of $2 \mathrm{M} \mathrm{HCl}$ were added to each of the cooled residues, and this was boiled for 10 minutes to convert Se (VI) to Se (IV). The sample solutions were neutralized using dilute sodium hydroxide solution and diluted to $25 \mathrm{~mL}$ by addition of $5 \mathrm{~mL}$ of $5 \%$ EDTA. Three milliliters each of these sample solutions were analyzed for selenium using the spectrophotometer.

2.6. Preparation of Selenium Standard Solution. One $\mathrm{mg} / \mathrm{mL}$ of standard selenium (IV) solution was prepared. Working standard solutions were prepared from dilutions of the standard solution. Thionin (TN) solution $(0.01 \%$, w/v) was prepared in $100 \mathrm{~mL}$ of distilled water containing $1 \mathrm{~mL}$ of $2 \mathrm{M}$ $\mathrm{HCl}$. Three milliliters each of the sample solutions were pipetted into clean $10 \mathrm{~mL}$ calibrated beakers. Two milliliters of $1 \%$ potassium iodide solution and $1 \mathrm{~mL}$ of $1 \mathrm{M} \mathrm{HCl}$ were added to the pipetted sample solutions and gently shaken until the appearance of yellow colour, indicating the liberation of iodine. Half a milliliter $(0.5 \mathrm{~mL})$ of $0.01 \% \mathrm{TN}$ solution was added to the solution mixtures and shaken for 2 minutes. The contents were then diluted to the $10 \mathrm{~mL}$ mark with distilled water and mixed well. The absorbances of the resulting solutions were measured at $600 \mathrm{~nm}$ against a blank solution that was prepared by replacing the analyte (selenium) solution with distilled water. The absorbance corresponding to the bleached colour, which in turn corresponds to the analyte (selenium) concentration, was obtained by subtracting the absorbance of the blank solution from that of the test solution. The amount of the selenium present in the volume taken was calculated from the calibration graph [25].

2.7. Trace Elements Extractabilities. The extractabilities of the trace elements were determined according to the method described by [26]. Half a gram $(0.5 \mathrm{~g})$ each of the three powdered samples (pulp, seeds and whole fruit) were weighed using the analytical balance and transferred into clean labelled tubes with caps. The weighed $T$. tetraptera samples were extracted with $0.03 \mathrm{M} \mathrm{HCl}$ (the approximate concentration of the acid found in the human stomach) by shaking at $37^{\circ} \mathrm{C}$ for 3 hours. The clear extracts obtained after filtration with filter paper were oven-dried at $100^{\circ} \mathrm{C}$ and wet acid-digested using a nitric/perchloric acid mixture. The amounts of trace elements $\mathrm{Fe}, \mathrm{Cu}, \mathrm{Mn}, \mathrm{Co}$, and $\mathrm{Zn}$ in the acid digest were determined using the flame atomic absorption spectrometer. The extractability of Se in the powdered samples was determined using a spectrophotometer.

2.8. Statistical Analysis. The data obtained after the experiment were analyzed using GraphPad Prism version 5.01 statistical package. The results were expressed as mean\pm standard deviation and presented using tables. The resulting data from the study were subjected to Analysis of Variance (ANOVA) using Tukey: compared all pairs of columns, at $95 \%$ confidence level. The $T$-test statistical tool was also used to compare the total trace elements and their extractabilities at $95 \%$ confidence level.

\section{Results and Discussion}

3.1. Vitamin A, C, E, and Beta-Carotene Content. For normal growth and development of the human body, vitamins are very important. Table 1 displays the various concentrations of vitamins (A, C, and E) and beta-carotene in the samples (pulp, seeds, and whole fruit) after analysis. These results obtained show that the concentrations of vitamin $\mathrm{E}$ and $\mathrm{C}$ appear to be relatively high, whereas those of vitamin $A$ and beta-carotene were low. The high levels of vitamin $\mathrm{E}$ and $\mathrm{C}$ recorded agree with the findings of Uyo et al. [4] in the same plant species.

The concentration of vitamin $\mathrm{E}$ was estimated to be in the order of seeds $>$ pulp $>$ whole fruit. This finding implies that vitamin $\mathrm{E}$ in the seeds and pulp, when mixed together, have an effect on the other. To support this assertion, the concentration of vitamin $\mathrm{E}$ in the whole fruit appeared to be lower than that of the seeds or pulp only. The concentration of vitamin C was also found to be higher in the seeds, followed by whole fruit and then the pulp. According to Lee and Kader [27], long storage condition is a factor that contributes to the loss of vitamin C available in plants. Since the seeds of $T$. tetraptera are located in the fruits and are shielded from environmental and storage conditions that may result in vitamin $\mathrm{C}$ decrement, the seeds are less likely to lose vitamin $\mathrm{C}$ than the pulp or whole fruit that are directly exposed to the environment, hence the abovementioned result for vitamin $\mathrm{C}$.

The composition of vitamin A was found to be higher in the seeds than in the pulp or whole fruit, as shown in Table 1, since oil is known to be present in large amounts in the seeds and occasionally in the fleshy parts of fruits of plants. Vitamin A is a fat-soluble vitamin; thus, its high concentration in the seeds of T. tetraptera may be attributed to the fact that vitamin A will readily be available in the seeds because of the high amount of oil present in the seeds than the pulp or whole fruit. The concentration of beta-carotene was also established to be higher in the seeds than the pulp or whole fruit. However, there was no significant difference between the three variables under study. The insignificance among the values obtained for the seeds, pulp, and whole fruit implies that there is no substantial effect of one concentration on the other of beta-carotene. Thus, whether the pulp or seeds are used separately or mixed together, the concentration of beta-carotene obtained will be virtually the same. The presence of these vitamins and beta-carotene in the fruit of $T$. tetraptera supports the use of the plant in many parts of Africa, particularly in Ghana [28].

3.2. Trace Elements Composition. The pulp, seeds, and whole fruit of T. tetraptera were found to contain varying amounts of trace elements that are essential in human nutrition. Table 2 shows the important variations of trace elements concentration in the fruit of $T$. tetraptera. The mean concentrations of trace elements were estimated to be in the order of $\mathrm{Fe}>\mathrm{Mn}>\mathrm{Zn}>\mathrm{Co}>\mathrm{Cu}>\mathrm{Se}$. This indicates that $T$. tetraptera has a high amount of $\mathrm{Fe}, \mathrm{Mn}, \mathrm{Zn}, \mathrm{Co}$, and $\mathrm{Cu}$ in 
TABle 1: Vitamin A, C, and E and beta-carotene composition in pulp, seeds, and whole fruit of T. tetraptera.

\begin{tabular}{lcccc}
\hline \multicolumn{3}{c}{ Attribute } \\
\hline Sample & Vitamin A (mg/g) & Vitamin C (mg/g) & Vitamin E (mg/g) & Beta-carotene $(\mathrm{mg} / \mathrm{g})$ \\
Pulp & $0.00319 \pm 0.0009^{\mathrm{a}}$ & $0.242 \pm 0.05^{\mathrm{b}}$ & $0.923 \pm 0.025^{\mathrm{b}}$ & $0.0068 \pm 0.002^{\mathrm{a}}$ \\
Seed & $0.00848 \pm 0.0030^{\mathrm{a}}$ & $0.880 \pm 0.18^{\mathrm{a}}$ & $2.617 \pm 0.201^{\mathrm{a}}$ & $0.0168 \pm 0.006^{\mathrm{a}}$ \\
W. fruit & $0.00679 \pm 0.0006^{\mathrm{a}}$ & $0.411 \pm 0.02^{\mathrm{b}}$ & $0.013 \pm 0.005^{\mathrm{c}}$ & $0.0136 \pm 0.001^{\mathrm{a}}$ \\
Sig. level & $0.1814 \mathrm{~ns}$ & $0.0027^{* *}$ & $<0.0001^{* * *}$ & $0.0851 \mathrm{~ns}$ \\
\hline
\end{tabular}

ns $=$ not significant (i.e., $p>0.05$ ); W. fruit $=$ whole fruit; ${ }^{* *}$ very significant (i.e., $p<0.01$ ); ${ }^{* *}$ extremely significant (i.e., $p<0.001$ ); and Sig. Level $=$ significance level. Means in a column with the same letter superscripts are not significantly different $(p>0.05)$, whereas means with different letter superscripts are significantly different $(p<0.05)$.

the fruit, which is comparable with the data reported by Akin-Idowu et al. [29].

3.2.1. Iron ( $\mathrm{Fe})$ Concentration. The iron concentration ( $\mathrm{mg} /$ $\mathrm{kg}$ ) in the pulp, seeds, and whole fruit of T. tetraptera was determined to be $162.00 \pm 7.14, \quad 115.00 \pm 12.00$, and $154.00 \pm 25.20$, respectively (Table 2), resulting in a mean of $143.67 \mathrm{mg} / \mathrm{kg}$. The mean obtained was higher than that reported earlier by Abii and Amarachi [30] in T. tetraptera fruit. The difference in concentrations may be as a result of the difference in iron content in the soil where the plants were located [31]. It was observed from Table 2 that there was no significant difference $(p>0.05)$ between the pulp and the whole fruit, as well as between the seeds and whole fruit. However, there was a significant difference $(p<0.05)$ between the pulp and the seeds, which indicates a wide range of iron content between the pulp and seeds as compared with the whole fruit. There was low iron content in the seeds compared with the pulp because the plant has the ability to accumulate more iron in the pulp than in the seeds. Iron is a vital component of myoglobin, a protein that provides oxygen to the muscles. Fe is also important for growth, development, normal cellular functioning, and synthesis of some hormones and connective tissue [32]. The recommended daily intake (RDI) for Fe is $15 \mathrm{mg}$ per day, and the values obtained in this study indicate that $T$. tetraptera is a good source of iron. This explains the use of the fruit by lactating mothers to regenerate lost blood [30].

3.2.2. Zinc ( $\mathrm{Zn})$ Concentration. Zinc content $(\mathrm{mg} / \mathrm{kg})$ in the pulp, seeds, and whole fruit of $T$. tetraptera was determined to be $31.60 \pm 4.77,43.40 \pm 5.29$, and $41.50 \pm 8.97$, respectively, as presented in Table 2. Although there was no significant difference $(p>0.05)$ between the pulp, seeds, and whole fruit, as illustrated in Table 2, the values obtained were observed to be higher as compared with a similar study by Akin-Idowu et al. [29], where a mean of $5.35 \mathrm{mg} / \mathrm{kg}$ was recorded for the pulp and $5.45 \mathrm{mg} / \mathrm{kg}$ for seeds. The high reported concentrations might be attributed to differences in zinc content in the soil where the plants were situated. Zinc is vital in wound healing, immune system function, prostaglandin production, bone mineralization, proper thyroid function, cognitive functions, fetal growth, blood clotting, and sperm production [33]. The RDI for $\mathrm{Zn}$ is $15 \mathrm{mg}$ per day, and the values obtained indicate that $T$. tetraptera is a good source of $\mathrm{Zn}$, supporting the native use of the fruit to treat diarrhoea and mental fatigue [34].

3.2.3. Copper (Cu) Concentration. The copper content (mg/ $\mathrm{kg}$ ) of $T$. tetraptera pulp, seeds, and whole fruit was also determined to be $16.10 \pm 4.98,11.90 \pm 8.40$, and $17.20 \pm 14.50$, respectively, as shown in Table 2 . There was no significant difference $(p>0.05)$ between the pulp, seeds, and whole fruit. The $\mathrm{RDI}$ for $\mathrm{Cu}$ is $2 \mathrm{mg}$ per day, and it is vital for iron metabolism, elastic tissue formation, skin and hair pigmentation, and other functions [8].

3.2.4. Manganese ( $\mathrm{Mn})$ Concentration. From Table 2, the manganese concentration $(\mathrm{mg} / \mathrm{kg})$ in the pulp, seeds, and whole fruit of $T$. tetraptera was determined to be $55.30 \pm 2.41,156.00 \pm 10.20$, and $122.00 \pm 5.29$, respectively. Significant differences $(p<0.05)$ were observed between the pulp, seeds, and whole fruit. This may be due to the ability of the plant to accumulate high manganese content in the fruit. The high manganese content in the seeds may be due to the fact that manganese is required for the synthesis of chlorophyll and assimilation of nitrate and activates enzymes of fat biosynthesis [34]. The mean concentration obtained was quite lower, but comparable with the $\mathrm{Mn}$ concentration range in a study conducted by Akin-Idowu et al. [29], in which $\mathrm{Mn}$ varied from $16.23 \mathrm{mg} / \mathrm{kg}$ to $178.90 \mathrm{mg} / \mathrm{kg}$. This may be attributed to the low concentration of manganese in the soil, resulting in its low availability in the plant [32]. The RDI for Mn is $5 \mathrm{mg}$ per day [35], and it is essential for a variety of metabolic processes, including those involved in energy metabolism, skeletal system development, and nervous system function and also serves as an antioxidant that prevents cell damage due to free radicals [36].

3.2.5. Cobalt (Co) Concentration. Cobalt concentration $(\mathrm{mg} / \mathrm{kg})$ in the pulp, seeds, and whole fruit of T. tetraptera samples was determined to be $38.10 \pm 6.40,21.10 \pm 7.15$, and $44.00 \pm 14.90$, respectively, as illustrated in Table 2 . There was no significant difference $(p>0.05)$ between the pulp, seeds, and whole fruit. Although there is no RDI for cobalt, an amount higher than $5 \mathrm{mg}$ per day is considered an overdose $[37,38]$. Cobalt is an important cofactor of enzymes involved in DNA biosynthesis, formation of neurotransmitters, and amino acid metabolism [39]. 
TABLE 2: Trace element composition in the fruit of Tetrapleura tetraptera.

\begin{tabular}{lcccccc}
\hline Sample & Fe $(\mathrm{mg} / \mathrm{kg})$ & $\mathrm{Zn}(\mathrm{mg} / \mathrm{kg})$ & $\mathrm{Cu}(\mathrm{mg} / \mathrm{kg})$ & $\mathrm{Mn}(\mathrm{mg} / \mathrm{kg})$ & $\mathrm{Co}(\mathrm{mg} / \mathrm{kg})$ & Se $(\mu \mathrm{g} / \mathrm{g})$ \\
\hline Pulp & $162.00 \pm 7.14^{\mathrm{a}}$ & $31.60 \pm 4.77^{\mathrm{a}}$ & $16.10 \pm 4.98^{\mathrm{a}}$ & $55.30 \pm 2.41^{\mathrm{a}}$ & $38.10 \pm 6.40^{\mathrm{a}}$ & $1.49 \pm 0.17^{\mathrm{a}}$ \\
Seeds & $115.00 \pm 12.00^{\mathrm{b}}$ & $43.40 \pm 5.29^{\mathrm{a}}$ & $11.90 \pm 8.40^{\mathrm{a}}$ & $156.00 \pm 10.20^{\mathrm{b}}$ & $21.10 \pm 7.15^{\mathrm{a}}$ & $2.43 \pm 0.28^{\mathrm{bc}}$ \\
W. fruit & $154.00 \pm 25.20^{\mathrm{ab}}$ & $41.50 \pm 8.97^{\mathrm{a}}$ & $17.20 \pm 14.50^{\mathrm{a}}$ & $122.00 \pm 5.29^{\mathrm{c}}$ & $44.00 \pm 14.90^{\mathrm{a}}$ & $2.97 \pm 0.27^{\mathrm{c}}$ \\
Mean & 143.67 & 38.83 & 11.73 & 111.10 & 34.40 & 2.30 \\
$p$ value & 0.0293 & 0.1396 & 0.7964 & $<0.0001$ & 0.0766 & 0.0009 \\
\hline
\end{tabular}

Note: $\mathrm{W}$. fruit $=$ whole fruit; values are means of triplicates \pm standard deviation. Means in a column with the same letter superscripts are not significantly different $(p>0.05)$; means in a column with different letter superscripts are significantly different $(p<0.05)$.

TABLE 3: HCl-extractable trace elements composition in the fruit of Tetrapleura tetraptera.

\begin{tabular}{lcccccc}
\hline Sample & $\mathrm{Fe}(\mathrm{mg} / \mathrm{kg})$ & $\mathrm{Zn}(\mathrm{mg} / \mathrm{kg})$ & $\mathrm{Cu}(\mathrm{mg} / \mathrm{kg})$ & $\mathrm{Mn}(\mathrm{mg} / \mathrm{kg})$ & $\mathrm{Co}(\mathrm{mg} / \mathrm{kg})$ & $\mathrm{Se}(\mu \mathrm{g} / \mathrm{g})$ \\
\hline Pulp & $101.00 \pm 1.39^{\mathrm{a}}$ & $22.60 \pm 3.06^{\mathrm{a}}$ & $10.30 \pm 2.03^{\mathrm{a}}$ & $40.80 \pm 1.57^{\mathrm{a}}$ & $27.70 \pm 5.12^{\mathrm{a}}$ & $1.00 \pm 0.15^{\mathrm{a}}$ \\
Seeds & $80.90 \pm 2.45^{\mathrm{b}}$ & $31.40 \pm 1.52^{\mathrm{b}}$ & $5.94 \pm 3.05^{\mathrm{a}}$ & $59.90 \pm 4.97^{\mathrm{b}}$ & $15.80 \pm 2.45^{\mathrm{b}}$ & $1.40 \pm 0.12^{\mathrm{ab}}$ \\
W. fruit & $95.30 \pm 2.64^{\mathrm{c}}$ & $31.70 \pm 1.42^{\mathrm{bc}}$ & $10.90 \pm 7.02^{\mathrm{a}}$ & $83.50 \pm 3.10^{\mathrm{c}}$ & $33.90 \pm 3.57^{\mathrm{a}}$ & $1.91 \pm 0.42^{\mathrm{b}}$ \\
Mean & 92.40 & 28.57 & 9.05 & 61.40 & 25.80 & 1.44 \\
$p$ value & $<0.0001$ & 0.0031 & 0.4060 & $<0.0001$ & 0.0034 & 0.0163 \\
\hline
\end{tabular}

Note: W. fruit $=$ whole fruit; values are means of triplicates \pm standard deviation. Means in a column with the same letter superscripts are not significantly different $(p>0.05)$. Means in a column with different letter superscripts are significantly different $(p<0.05)$.

3.2.6. Selenium (Se) Concentration. Selenium concentration $(\mu \mathrm{g} / \mathrm{g})$ in the pulp, seeds, and whole fruit of T. tetraptera samples was also determined to be $1.49 \pm 0.17,2.43 \pm 0.28$, and $2.97 \pm 0.27$, respectively, as displayed in Table 2 . There was a significant difference $(p<0.05)$ between the pulp and seeds, as well as the whole fruit, but there was no significant difference between the seeds and the whole fruit. This is due to the low concentration of selenium in the pulp as a result of the inability of the plant to accumulate selenium in the pulp. Selenium content was found to present the lowest levels of the trace elements determined. However, it was higher than the concentration obtained in a study conducted by Arinola et al. [40], in which $50.0 \mu \mathrm{g} / 100 \mathrm{~g}$ of Se was reported. The high selenium concentration may be due to high availability of selenium in the soil where the plant was found. The RDI for Se in children and adults is $20 \mu \mathrm{g} /$ day and $55 \mu \mathrm{g} / \mathrm{day}$, respectively [41]. Selenium is known to be involved in several major metabolic pathways, including thyroid hormone metabolism, antioxidant defense systems, and immune function [42].

In this study, higher trace element concentrations were obtained as compared with earlier studies. This is due to the dependence of the plant on the availability of elements in the plant's growth media (soil, nutrient solution, and water) [32]. Thus, higher trace element concentrations in a soil may reflect in higher trace element accumulations in a plant. The bioavailability of trace minerals in plants is also dependent on the plant's ability to absorb trace minerals and the rate at which the roots absorb them $[43,44]$.

3.3. HCl-Extractable Trace Elements. The HCl-extractable trace elements were determined according to a method described by Suha and Babiker [26]. The method was employed to determine how much of total trace element would be absorbed into the body. Table 3 shows the $\mathrm{HCl}$ extractable trace elements composition in T. tetraptera fruit from which it can observed that there was a significant difference $(p<0.05)$ between the pulp, seeds, and whole fruit for $\mathrm{HCl}$-extractable trace elements, namely $\mathrm{Fe}$ and $\mathrm{Mn}$. Again, there was a significant difference $(p<0.05)$ between the pulp and seeds, as well as pulp and whole fruit for $\mathrm{HCl}$ extractable $\mathrm{Zn}$, but no significant difference $(p>0.05)$ was noted between the seeds and whole fruit. This may be as a result of absorptive interactions between iron, zinc, and copper. Zinc inhibits copper absorption [12]. There was also no significant difference $(p>0.05)$ between the pulp, seeds, and whole fruit for the $\mathrm{HCl}$-extractable $\mathrm{Cu}$. This indicated that the amounts of $\mathrm{Cu}$ extracted at the various sections of the fruit were statistically similar. Trace element extractability is complicated and dependent on a number of factors related to mineral solubility and absorbability in the body. The poor mineral extractabilities may be as a result of the ability of some minerals to inhibit the absorption of others. For example, there are absorptive interactions between calcium and magnesium and also between iron, zinc, and copper [45].

3.4. Extractabilities (\%) of Trace Elements. The extractabilities of trace elements in the various sections of the fruit were also determined as displayed in Table 4. No significant difference $(p>0.05)$ was observed in the pulp, seeds, and whole fruit for trace elements $\mathrm{Fe}, \mathrm{Zn}, \mathrm{Cu}, \mathrm{Co}$, and Se. This indicates that the extractabilities of these trace elements in the pulp, seeds, and whole fruit were statistically similar. However, there was a significant difference $(p<0.05)$ between the pulp, seeds, and whole fruits for manganese. This was due to lower $\mathrm{HCl}$-extractable $\mathrm{Mn}$ in the seeds, resulting in low manganese extractability $(38.30 \pm 1.39)$ as compared with the high extractabilities in the pulp $(73.70 \pm 2.91)$ and the whole fruit $(68.70 \pm 3.72)$. The low manganese extractability was as a result of absorptive interaction between $\mathrm{Mn}$ and Fe. High iron contents suppress the extraction of manganese [46, 47]. Mineral extractability in the body is affected by inhibitory and/or accelerating factors such as 
TABle 4: Trace elements extractabilities (\%) in the fruit of Tetrapleura tetraptera.

\begin{tabular}{lcccccc}
\hline Sample & $\mathrm{Fe}(\mathrm{mg} / \mathrm{kg})$ & $\mathrm{Zn}(\mathrm{mg} / \mathrm{kg})$ & $\mathrm{Cu}(\mathrm{mg} / \mathrm{kg})$ & $\mathrm{Mn}(\mathrm{mg} / \mathrm{kg})$ & $\mathrm{Co}(\mathrm{mg} / \mathrm{kg})$ & $\mathrm{Se}(\mu \mathrm{g} / \mathrm{g})$ \\
\hline Pulp & $62.60 \pm 3.75^{\mathrm{a}}$ & $73.10 \pm 17.80^{\mathrm{a}}$ & $67.00 \pm 23.00^{\mathrm{a}}$ & $73.70 \pm 2.91^{\mathrm{a}}$ & $72.60 \pm 1.37^{\mathrm{a}}$ & $67.00 \pm 3.99^{\mathrm{a}}$ \\
Seeds & $70.80 \pm 8.71^{\mathrm{a}}$ & $72.80 \pm 7.27^{\mathrm{a}}$ & $56.80 \pm 14.60^{\mathrm{a}}$ & $38.30 \pm 1.39^{\mathrm{b}}$ & $79.50 \pm 20.90^{\mathrm{a}}$ & $58.00 \pm 2.41^{\mathrm{a}}$ \\
W. fruit & $62.90 \pm 10.00^{\mathrm{a}}$ & $78.90 \pm 17.17^{\mathrm{a}}$ & $71.10 \pm 14.30^{\mathrm{a}}$ & $68.70 \pm 3.72^{\mathrm{c}}$ & $80.70 \pm 16.30^{\mathrm{a}}$ & $63.70 \pm 8.54^{\mathrm{a}}$ \\
Mean & 65.43 & 74.93 & 64.97 & 60.23 & 77.60 & 62.90 \\
$p$ value & 0.4102 & 0.8559 & 0.6206 & $<0.0001$ & 0.7910 & 0.2170 \\
\hline
\end{tabular}

Note: W. fruit $=$ whole fruit; values are means of triplicates \pm standard deviation. Means in a column with the same letter superscripts are not significantly different $(p>0.05)$. Means in a column with different letter superscripts are significantly different $(p<0.05)$.

phytates, fiber, ascorbic acid, and tannins as well as absorptive interactions between certain minerals [11,47]. In general, it was observed that the extracted amounts of trace elements depended on their availability. Thus, the higher the trace element, the higher its extractability.

\section{Conclusion}

The study showed that Tetrapleura tetraptera fruits contain varying concentrations of vitamins and trace elements, depending on the part of the fruit (pulp, seeds, and whole fruit), which are comparable with other studies reported in the literature. The extractabilities of the trace elements in the $T$. tetraptera fruits were in the order $\mathrm{Co}>\mathrm{Zn}>\mathrm{Fe}>\mathrm{Cu}>\mathrm{Se}>\mathrm{Mn}$. Generally, significant amounts of trace elements are expected to be extracted after consumption of $T$. tetraptera fruits. Therefore, the plant holds a terrific promise in providing nutrient supply that could promote good health, which justifies and confirms the traditional use of the fruits as food and vitamin source in many parts of West Africa.

\section{Data Availability}

The data used to support the findings of this study are enclosed within the article. Additional data are accessible from the corresponding author upon request.

\section{Conflicts of Interest}

The authors declare that there are no conflicts of interest regarding the publication of this paper.

\section{Acknowledgments}

The authors wish to express their heartfelt gratitude to the Department of Chemistry, University of Cape Coast, Ghana, for providing them with laboratory facilities for this research.

\section{References}

[1] C. Orwa, A. Mutua, R. Kindt, R. Jamnadass, and S. Anthony, Agroforestry Database: A Tree Reference and Selection Guide Version 4, pp. 1-5, World Agroforestry Centre, Nairobi, Kenya, 2009.

[2] A. S. Adebayo, I. A. Gbadomosi, and C. O. Adewunmi, "Formulation of antimicrobial dried powdered herbs in soap basis," in Phyto Medicines in Malaria and Sexually Transmitted Disease, Challenges for the New Millennium, C. O. Adewunmi and S. K. Adesina, Eds., vol. 97, Obafemi Awolowo University, Ile-Ife, Nigeria, 2000.
[3] E. O. Nwaichi, "Effect of heat treatment on the antioxidant properties of Tetrapleura tetraptera, xylopiaaethiopica and Piper guineense," International Journal of Biotechnology and Food Science, vol. 1, no. 1, pp. 1-5, 2013.

[4] E. A. Uyo, E. E. Ita, and G. E. Nwofia, "Variability in nutritional traits in Tetrapleura tetraptera (schum and thonn.) taub. From cross river state, Nigeria," Pakistan Journal of Nutrition, vol. 12, no. 8, pp. 701-707, 2013.

[5] Adewunmi, C. O., Potential Uses of Tetrapleura tetraptera (Taub.) (Minosaceae), Science in Africa; Africa's First On-Line Science Magazine, 2004, http://www.science in Africa co: 29/3 Plant.1.htm.

[6] J. A. O. Ojewole and C. O. Adewunmi, "Antiinflammatory and hypoglycaemic effects of Tetrapleura tetraptera Taub fruit aqueous extract in rats," Journal of Ethnopharmacology, vol. 95, no. 2-3, pp. 177-182, 2004.

[7] D. Eruvbetine, Canine Nutrition and Health, Kensington Pharmaceuticals Nig. Ltd., Lagos, Nigeria, 2003.

[8] S. Saracoglu, M. Tuzen, and M. Soylak, "Evaluation of trace element contents of dried apricot samples from Turkey," Journal of Hazardous Materials, vol. 167, no. 1-3, pp. 647-652, 2009.

[9] R. J. Wood, "Assessment of marginal zinc status in humans," The Journal of Nutrition, vol. 130, no. 5, pp. 1350S-1354S, 2000.

[10] F. A. Kaneeez, M. A. Quadiruddin, A. M. Kalhoo, and S. Y. Badar, "Determination of major and trace elements in artemissiadegatissina and rhayastrida and their relative medicinal uses," Pakistan Journal of Scientific and Industrial Research, vol. 44, pp. 291-293, 2001.

[11] J. Parada and J. M. Aguilera, "Food microstructure affects the bioavailability of several nutrients," Journal of Food Science, vol. 72, no. 2, pp. R21-R32, 2007.

[12] D. Bosscher, M. Van Caillie-Bertrand, and H. Deelstra, "Effect of thickening agents, based on soluble dietary fiber, on the availability of calcium, iron, and zinc from infant formulas," Nutrition, vol. 17, no. 7-8, pp. 614-618, 2001.

[13] Y. Li and H. E. Schellhorn, "New developments and novel therapeutic perspectives for vitamin C," Journal of Nutrition, vol. 137, no. 10, pp. 2171-2184, 2007.

[14] M. G. Traber, M. E. Shils, M. Shike et al., Vitamin E, Lippincott Williams \& Wilkins, Philadelphia, PA, USA, 10th edition, 2006.

[15] S. Mannisto, S. A. Smith-Warner, and D. Spiegelman, "Dietary carotenoids and risk of lung cancer in a pooled analysis of seven cohort studies," Cancer Epidemiology Biomarkers \& Prevention, vol. 13, no. 1, pp. 40-48, 2004.

[16] G. O. Babarinde and O. A. Fabunmi, "Effects of packing materials and storage temperature on quality of fresh okra (Abelmoschus esculentus) Fruit," Agricultural Tropica et Subtropica, vol. 42, no. 4, pp. 151-156, 2009.

[17] A. Aumaporn, "Effects of moisture heating and vacuum fry on organic and conventional okra quality," Asian Journal of Food and Agro-Industry, vol. 2, pp. 318-324, 2009.

[18] C. H. Jun, G. B. Zhong, L. C. Ying, L. H. Guang, Y. Q. Li, and L. R. Jun, "Study on content determination of vitamin and $\mathrm{E}$ in 
white yak's milk by HPLC," Journal of Gansu Agricultural University, vol. 2, pp. 108-111, 2007.

[19] M. Rutkowski and K. Grzegorczyk, "Modifications of spectrophotometric methods for antioxidative vitamins determination convenient in analytic practice," Acta Scientiarum Polonorum: Technologia Alimentaria, vol. 6, no. 3, pp. 17-28, 2007.

[20] D. A. Bekele and G. S. Geleta, "Iodometric determination of the ascorbic acid (vitamin C) content of some fruits consumed in jimma town community in Ethiopia," Research Journal of Chemical Science, vol. 5, no. 1, pp. 60-63, 2015.

[21] J. Haan, Experiments for Quantitative Analysis Laboratory Fullerton, Montezuma Publishing, Washington, DC, USA, 2nd edition, 2015.

[22] R. Sami, Y. Li, B. Qi et al., "HPLC analysis of water-soluble vitamins (B2, B3, B6, B12, and C) and fat-soluble vitamins (E, $\mathrm{K}, \mathrm{D}, \mathrm{A}, \& \beta$-carotene) of okra (Abelmoschus esculentus)," Journal of Chemistry, vol. 2014, Article ID 831357, 6 pages, 2014.

[23] R. R. Eitenmiller, L. Ye, and W. O. Landen, Vitamin Analysis for the Health and Food Sciences, Taylor \& Francis Group: CRC Press, Boca Raton, FL, USA, 2nd edition, 2008.

[24] A. B. M. H. Uddin, R. S. Khalid, M. Alaama, A. M. Abdualkader, A. Kasmuri, and S. A. Abbas, "Comparative study of three digestion methods for elemental analysis in traditional medicine products using atomic absorption spectrometry," Journal of Analytical Science and Technology, vol. 7, no. 1, 2016.

[25] H. D. Revanasiddappa and T. N. Kiran Kumar, "A facile spectrophotometric method for the determination of selenium," Analytical Sciences, vol. 17, no. 11, pp. 1309-1312, 2001.

[26] A. O. Suha and E. E. Babiker, "Quality of protein and minerals as influenced by antinutrients of grains of sorghum cultivars grown under different levels of micronutrient," International Food Research Journal, vol. 22, no. 6, pp. 2237-2243, 2015.

[27] S. K. Lee and A. A. Kader, "Preharvest and postharvest factors influencing vitamin C content of horticultural crops," Postharvest Biology and Technology, vol. 20, no. 3, pp. 207-220, 2000.

[28] O. O. Akintola, A. Bodede, and O. R. Ogunbanjo, "Nutritional and medicinal importance of Tetrapleura tetraptera fruits (aridan)," African Journal of Science and Research, vol. 6, no. 4, pp. 33-38, 2015.

[29] P. E. Akin-Idowu, D. O. Ibitoye, O. T. Ademoyegun, and O. T. Adeniyi, "Chemical composition of the dry fruit ofTetrapleura tetrapteraand its potential impact on human health," Journal of Herbs, Spices \& Medicinal Plants, vol. 17, no. 1, pp. 52-61, 2011.

[30] T. A. Abii and E. Amarachi, "Investigation into the chemical composition of the dry fruit of Tetrapleura tetraptera (ubukirihu)," Journal of Food Science and Technology, vol. 5, no. 3, pp. 229-232, 2007.

[31] A. Kabata-Pendias and A. Mukherjee, Trace Elements from Soil to Human, Springer-Verlag Berlin Heidelberg, Berlin, Germany, 2007.

[32] L. Grillet, S. Mari, and M. Schmidt, "Iron in seeds-loading pathways and subcellular localization," Frontiers in Plant Science, vol. 4, 2014.

[33] O. G. Arinola, "Essential trace elements and metal binding proteins in Nigerian consumers of alcoholic beverages," Pakistan Journal of Nutrition, vol. 7, no. 6, pp. 763-765, 2008.

[34] K. F. Sadler, "Neuropsychopharmacology," Biopsy Chemistry, vol. 28, pp. 181-190, 2004.
[35] T. Ducic and A. Polle, "Transport and detoxification of manganese and copper in plants," Brazilian Journal of Plant Physiology, vol. 17, no. 1, pp. 103-112, 2005.

[36] ASTDR, Toxicological Profile for manganese, US Department of Health and Human Services, Health and Human Services, Agency for Toxic Substances and Disease Registry, Atlanta Georgia, 2000.

[37] RDI, "Reference daily intake of vitamins, minerals and other nutrients," 2009, http://en.wikipedia.org/wiki/Reference_ Daily_Intake.

[38] R. K. Murray, D. K. Granner, P. A. Mayes, and V. W. Rodwell, Harper's Biochemistry, McGraw-Hill, Health Profession Division, New York, NY, USA, 25th edition, 2000.

[39] J. Gál, A. Hursthouse, P. Tatner, F. Stewart, and R. Welton, "Cobalt and secondary poisoning in the terrestrial food chain: data review and research gaps to support risk assessment," Environment International, vol. 34, no. 6, pp. 821-838, 2008.

[40] O. G. Arinola, S. O. Nwozo, J. A. Ajiboye, and A. H. Oniye, "Evaluation of trace elements and total antioxidant status in Nigerian cassava processors," Pakistan Journal of Nutrition, vol. 7, no. 6, pp. 770-772, 2008.

[41] A. A. Bouba, N. Y. Njintang, H. S. Foyet, J. Scher, D. Montet, and C. M. F. Mbofung, "Proximate composition, mineral and vitamin content of some wild plants used as spices in Cameroon," Food and Nutrition Sciences, vol. 3, no. 4, pp. 423-432, 2012.

[42] K. Brown and J. Arthur, "Selenium, selenoproteins and human health: a review," Public Health Nutrition, vol. 4, no. 2B, pp. 593-599, 2001.

[43] Institute of Medicine, "Selenium," in Dietary Reference Intakes for Vitamin C, Vitamin E, Selenium and Carotenoids, National Academy Press, Washington, DC, USA, 2000.

[44] W. J. G. M. Peijnenburg and T. Jager, "Monitoring approaches to assess bioaccessibility and bioavailability of metals: matrix issues," Ecotoxicology and Environmental Safety, vol. 56, no. 1, pp. 63-77, 2003.

[45] K. Hund-Rinke and W. Kördel, "Underlying issues in bioaccessibility and bioavailability:,"Ecotoxicology and Environmental Safety, vol. 56, no. 1, pp. 52-62, 2003.

[46] J. L. Aschner and M. Aschner, "Nutritional aspects of manganese homeostasis," Molecular Aspects of Medicine, vol. 26, no. 4-5, pp. 353-362, 2005.

[47] Institute of Medicine, Dietary Reference Intakes: Vitamin A, Vitamin K, Arsenic, Boron, Chromium, Copper, Iodine, Iron, Manganese, Molybdenum, Nickel, Silicon, Vanadium, and Zinc, National Academy Press, Washington, DC, USA, 2001. 

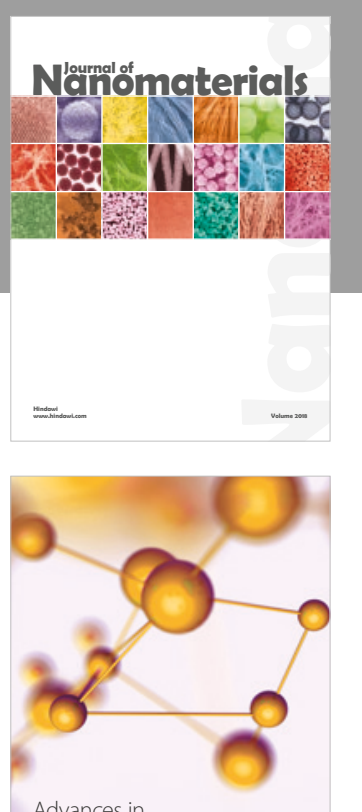

Physical Chemistry
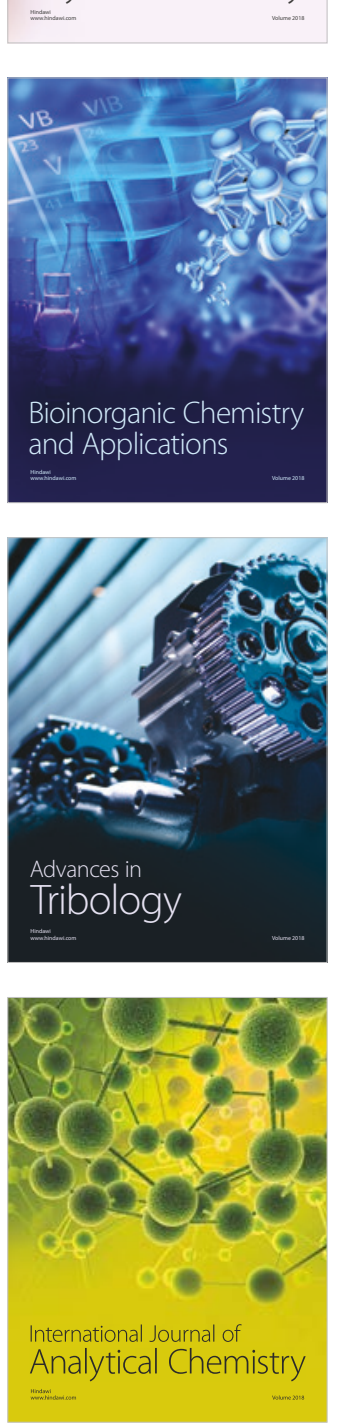

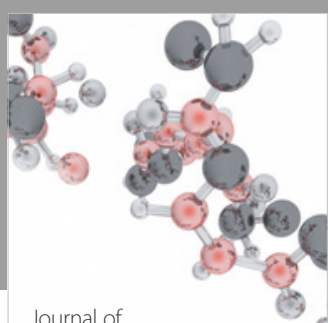

Analytical Methods

in Chemistry

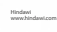

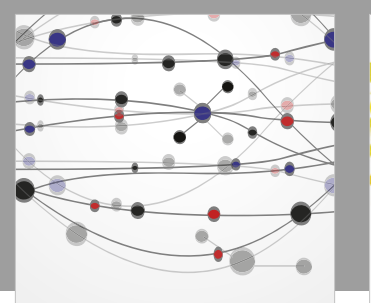

The Scientific World Journal

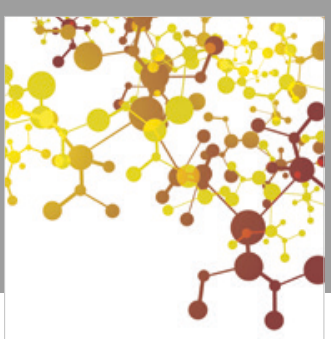

Journal of

Applied Chemistry
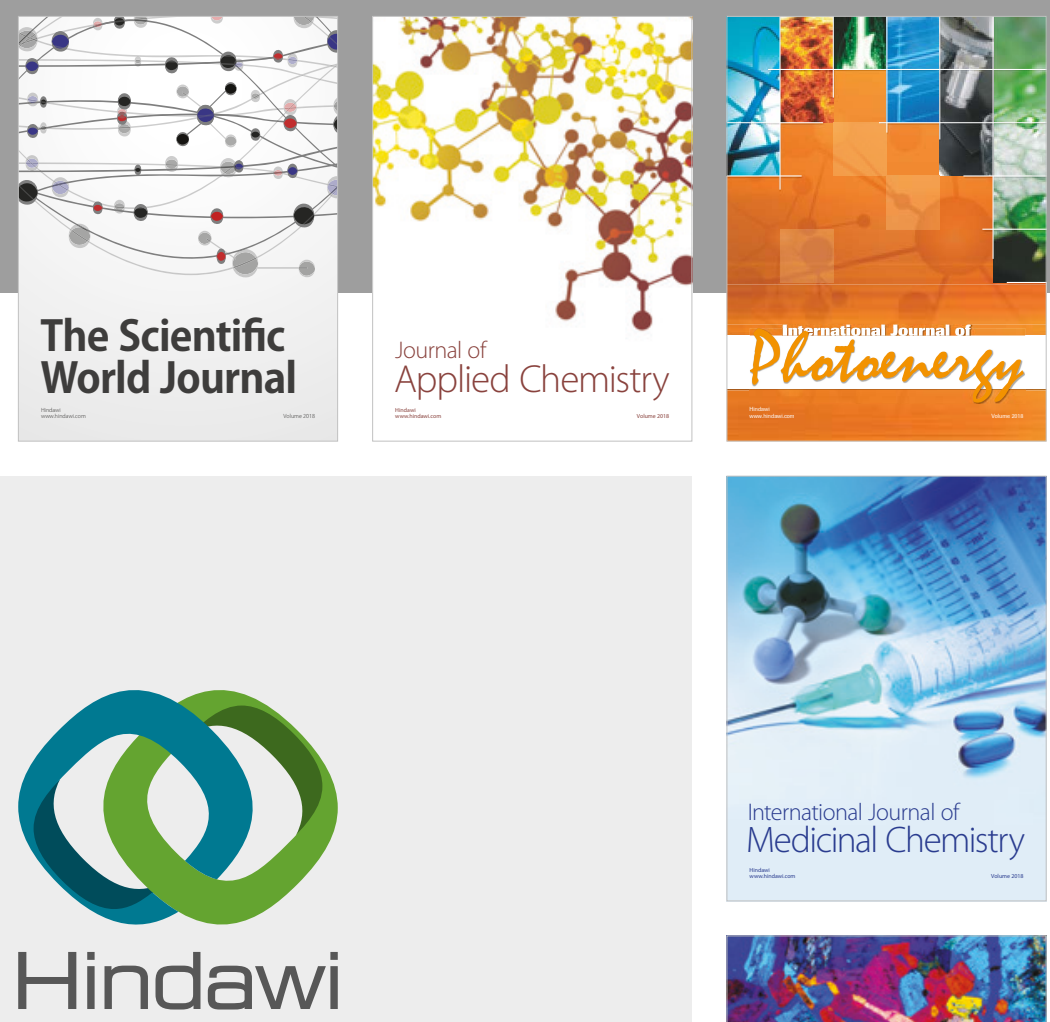

Submit your manuscripts at

www.hindawi.com
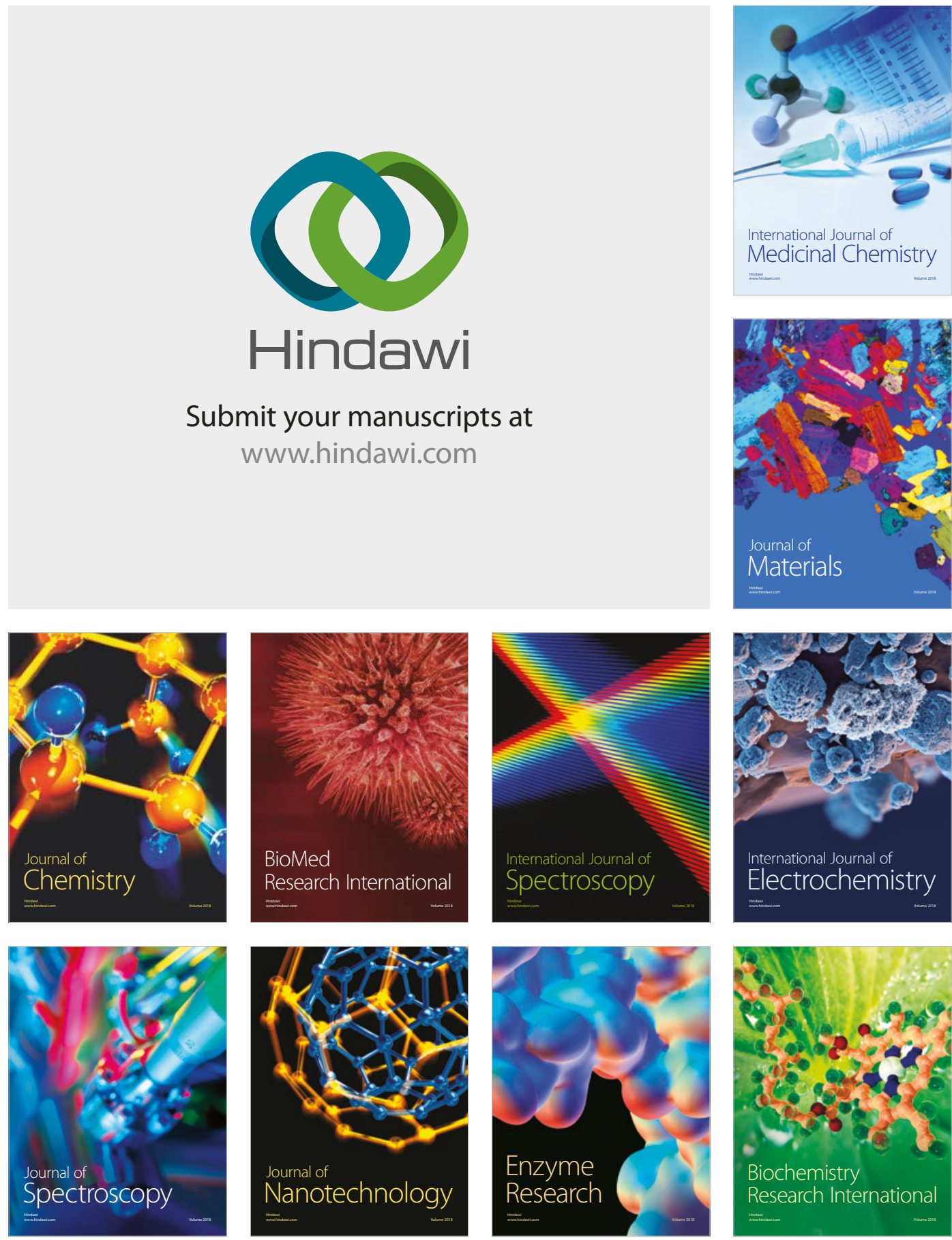
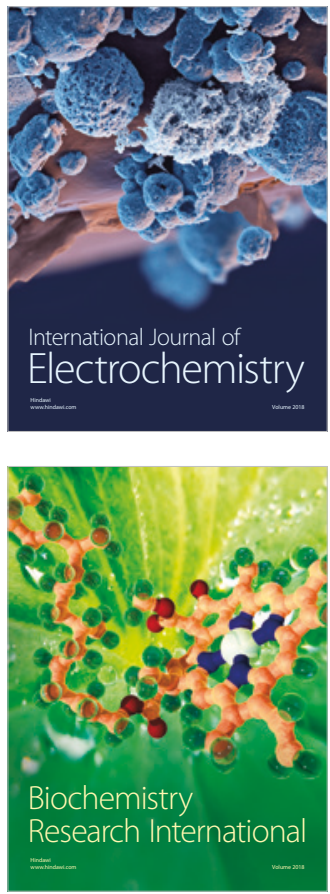